Patricia Muñoz-Cabrera'

'Universidade de São Paulo, São Paulo, SP, Brazil

Patricia Duarte Rangel ${ }^{2}$

${ }^{2}$ Freie Universität Berlin, Berlin, Germany

\title{
Gender Justice in Feminist Analysis of Public Policies in Argentina, Brazil and Chile
}

\begin{abstract}
This paper presents part of the authors' postdoctoral research at the University of São Paulo, Brazil. It focuses on the transformation processes triggered by feminist-driven governmental actions in Brazil, Argentina and Chile over the last few years, especially during the terms of Cristina Fernández, Dilma Rousseff and Michele Bachelet. Using concepts and theoretical insights from specialized literature, we address questions about lobbying and disputes in the political arena in order to understand the impact of feminisms on public policies, and the extent to which these policies relate to the intersectional nature of discrimination (gender, race / ethnicity, class). Four major public policies areas are examined, namely economic autonomy, social facilities, health, and violence, from three analytical angles: 1) the role of women's policy agencies in policy making processes; 2) Gender-Aware Public Policies during the mandates of female presidents in Argentina, Brasil e Chile; 3) the intersectionality of gender justice in public policy-making.

Keywords: Gender-based public policies, intersectionality, South America, female presidents, gender justice.
\end{abstract}

\section{Introduction}

This paper summarises key aspects of ongoing postdoctoral research by the authors, ${ }^{1}$ and insights from seminal discussions on gender equality in public policies held within the

\section{cc) (i)}

Esta obra está sob licença Creative Commons.

${ }^{1}$ This work has been done thanks to post-doctoral scholarships by FAPESP - Fundação de Amparo à Pesquisa do Estado de São Paulo (FAPESP), (processos 14/13248-3, 15/26734-6, 16/16392-3; and12/23065-8). The authors are grateful for the support received. Opinions, hypotheses, conclusions and recommendations contained in this paper are the authors' responsibilities and do not necessarily reflect the views of FAPESP. 
feminist research group " 50 years of feminism [1965-2015]: New Paradigms, Future Challenges - Argentina, Brazil and Chile". ${ }^{2}$ Its main focus is examination of the transformation processes triggered by feminist-driven governmental actions in Brazil, Argentina and Chile over the last few years, especially during the terms of Cristina Fernández, Dilma Rousseff and Michele Bachelet. Building upon concepts and theoretical insights from specialized literature, it addresses questions about lobbying and disputes in the political arena in order to understand the impact of feminisms on selected areas of public policies, and the extent to which these policies relate to the intersectional nature of discrimination in material reality (gender, race / ethnicity, class). The discussion hinges upon three analytical angles: 1) the role of women's policy agencies (WPAs) and femocrats in policy making processes; 2) Gender-Aware Public Policies during the mandates of female presidents in Argentina, Brasil e Chile; 3 ) the intersectionality of gender justice in public policy-making.

The paper is structured as follows. The first section includes a theoretical discussion on the role of women's political agencies (WPAs) and femocrats in processes of formulation and approval of gender-aware public policies, highlighting the limitations of feminist institutional actions. Secondly, it examines feminisms' contribution to gender equality public policies (in particular economic autonomy, social equipments, violence and health). Thirdly, it problematises the correlation between public policies promoting gender equality and intersectional discrimination. This seminal discussion is done through three major areas of gender justice in public policies: a) convergences and dissonances in feminist approaches; b) the role of the State to ensure de jure and de facto equality, and c) the complexity inherent in recognition and distributive policy-making policies attempting to redress inequalities through recognition and distributive justice policy-making.

\section{The role of women's policy agencies in policy-making processes}

In order to comprehend gender mainstreaming and policy making in Argentina, Brazil and Chile, one must address the links between the three countries' feminist movements and women's policy agencies in post-dictatorship contexts. The interaction among these two distinct actors is often addressed as "state feminism" (MCBRIDE; MAZUR, 2012). This concept relates to a specific kind of alliance between women's movements, women's policy agencies (WPAs) $^{3}$ and the state, and was coined in order to make women's interests gain access to policy arenas. ${ }^{4}$

Since the ratification of the UN Convention on the Elimination of All Forms of Discrimination against Women (CEDAW), committing governments to take measures against gender inequity and inequality, WPAs have played an important role. Most states established their first WPAs in the 1970s and 1980s, inaugurating a new phase in the relations between feminist movements and the state. The first Brazilian WPA (National Council for Women's Rights, established by Law $n^{\circ}$ 7.353/85) was set up two years before Argentina launched their Women's Sub-secretariat. In this country, a Public Policy Coordinating Council was created in 1991, to be finally replaced by the National Women's Council (Decree $\left.n^{\circ} 1.426 / 92\right)$. That same year, Chile instituted the National Women's Service - SERNAM (Law n 19.023/91).

\footnotetext{
2"50 Anos de Feminismo (1965-2015): Novos Paradigmas, Desafios Futuros - Argentina, Brasil e Chile", Department of Sociology, University of São Paulo. Processo Fapesp: 12/23065-8.

${ }^{3} \mathrm{~A}$ women's policy agency (WPA) is the smallest unit of the state structures designated to develop policies to redress gender inequality and to promote women's rights (Scheidegger 2014).

${ }^{4}$ See also Hernes 1987; Sawer 1990; Eisenstein 1990, Outshoon 1994; Lovenduski 2005; McBride \& Mazur 2010; Scheidegger, 2014.
} 
During the 1990's and early 2000's, Latin America witnessed the advent of a new correlation of forces, with the emergence of progressive governments and focus on the state's social functions (PARADIS, 2013). Thus, a second and more institutionalized generation of WPAs emerged: The Women's Policy Office name SPM was created in Brazil by Law no 10.683/2003 (abolished by president Michel Temer in 2016). More recently, Chile established a Ministry of Women and Gender Equality (Law $n^{\circ} 20.820 / 2015$ ).

The recent institutionalization and proliferation of WPAs in those countries revived the notion of "state feminism". However, a first fundamental question to consider is its geopolitical provenance - the Global North. A major problematic aspect relates to the appropriation of "state feminism" by researchers from countries which were colonised (and to some extent still are) by the very Nation-states that forged this analytical framework. From a post-colonial or coloniality-of-power standpoint, the notion of "state feminism" does not fully embrace the realities of Global South nations (MUÑOZ-CABRERA, 2015). Acknowledging its limitations, Bohn (2010) indicates that, although they are not the only strategy to diminish gender inequality, WPAs still play a key role as they can compellingly voicesome of the strategic claims made by women's movements. Accurate as the critiques may be, "state feminism" and WPAs have benefited women's movements, in that they have empowered feminist movements to conquer more space within the state.

A second fundamental question is the nature of the state itself. A state's capacity to guarantee and promote economic equity, equality, and social well-being of all citizens is undermined when gender equality becomes an instrument of political hegemony. In some cases, focus on gender mainstreaming has deviated policy attention from women's human rights and jeopardized progress towards gender policies that are non-discriminatory from an intersectional viewpoint, namely policies that bear a concern with race, class and gender intersections affecting women's political participation. Overlooking this debate can hamper WPAs' ability to contribute to sustainable improvements in women's political representation (MUÑOZ-CABRERA, 2015). Considering the above, when it comes to deeper and sustainable transformation of complex power relations, the potential of "state feminism" as an emancipatory paradigm proves insufficient, both from a theoretical and a political standpoint. Here, an intersectional approach (often referred to as "multiple discrimination") proves necessary, as discussed in the third section.

Finally, it is important to note that the background of this debate is as relevant as the "state feminism" analysis itself: the role of political institutions and the state. It is necessary to further explore the theoretical concepts and empirical expressions of such a disputed term. Furthermore, contextual specificities of WPAs in the Global South deserve throughout analysis. A major challenge facing women's policy agencies in Latin America is the lack of human resources, budget limitations, insufficient political sensitivity from public institutions and actors, as well as resistance from other government bodies (GUZMÁN, 2006, MONTAÑO, 2006, apud PARADIS, 2013). These challenges pose a threat to their existence. Political disruptions as the recent coup-d'état in Brazil (2016) and the subsequent dismantling of Secretaria de Políticas para Mulheres (SPM) shows how fragile gender-responsive institutions still are and how gender mainstreaming has not been systematically implemented in our continent.

\section{Gender-Aware public policies during the mandates of female presidents in Argentina, Brazil and Chile}

As a result of what has been previously discussed, a fundamental question can be raised: did WPAs manage to bring about concrete improvements in terms of gender equality? This section attempts to offer some answers, presenting an overview of gender-relevant 
governmental actions undertaken during the mandates of Cristina Fernández de Kirchner in Argentina (2007-2011; 2011-2015), Dilma Rousseff in Brazil (2010-2014; 2014-2016) and Michelle Bachelet in Chile (2006-2010; 2014-2018). ${ }^{5}$ The discussion examines four public policies areas: economic autonomy, social facilities, health, and violence.

Economic autonomy is a key domain for women's emancipation. It includes several specific policies, such as vocational training to enhance women's insertion in labour markets, tackling the gender wage-gap, and female entrepreneurship. In Argentina, apart from a programme on regulation of the domestic work sector, little was done in this respect. InBrazil, actions were undertaken to enhance women's access to labour market (training, skillsenhancement, kindergarten availability, micro-entrepreneurship, to name but a few). One important action was a constitutional amendment that led to legislative changes to improve the status of domestic workers. In Chile, Pdt.Bachelet achieved policy improvements in women's status in labour market and domestic workers' conditions (Law 2008) but met with resistance to approve laws to reduce gender discrimination in labour markets. She managed, however, to move forward in 2009 , when an amendment to the employment law added the commitment to reduce the wage gap between women and men (which, according to feminist activists, does not contain any mechanism to guarantee compliance with this intention).

In addition to this, initiatives were taken in the domain of poverty eradication, in particular, through cash transfers to low-income households. Some relevant examples are Bolsa Família in Brazil, Asignación Universal por Hijo (AUH) in Argentina, and the Chilean programme Bono por hijo and solidarity basic pension for people within the $60 \%$ lowest income. Thanks to these policy actions, extreme poverty decreased (TIELEMANS, 2014 and JALALZAI, 2015).

Regarding social facilities for social protection, during Bachelet's office, actions aimed at enhancing women's autonomy included an increase in crèches availability such as the program Chile Crece Contigo. The goal of this program is to ensure access to day care/ kindergaten and preschool free of charge for children from poor households. The WPA "National Service for Women" (SERNAM) was key in achieving this. In Brazil, the program Brasil Carinhoso benefitted children from 0 to 6 years of age, focusing on increasing the number of kindergartens and pre-schools in the country. In Argentina, little progress was made.

Examining actions to fight violence against women (VAW), several improvements were achieved. During Fernández de Kirchner's mandate, a law was passed aiming at eradicating violence against women (Law 26.458/2009). Progressive as it may have been, this Law was not implemented during her office. In Brazil, a second Gender Equality National Plan (II Plano Nacional de Políticas para as Mulheres: 2008-201 1) was approved in 2007. This Plan included improvements in access to shelters by women victims of VAW (it planned to build 764 units for victims of gender violence and the training of 573.000 professionals), and gender-awareness of public officials. Prior to Rousseff's term, the Maria da Penha Law had been passed in 2006, after a long struggle by feminist and women's movements. Drafted by a group of legal experts and feminist NGOs, this Law reshaped Brazilian public policy landscape. In Chile, Bachelet strongly supported a bill to combat gender-based violence and increased the number of shelters for victims of domestic violence. The president allocated twice more resources to the budget of these shelters than her predecessor, President Ricardo Lagos.

In the area of women's integral health, some improvements were made under Pdt Fernández de Kirchner, for example, the Programa Nacional de Salud Sexual y Procreación

${ }^{5}$ The data was collected by Lucia Avelar and Patricia Rangel from different sources. The result was a huge amount of actions which in this paper appear clustered in four main areas. The research was done in the framework of the Fapesp research project " 50 Years of Feminism (1965-2015): Argentina, Brazil and Chile". See Avelar \& Rangel, 2017.

4 Revista Estudos Feministas, Florianópolis, 26(3): e58565 
Responsable (Law of 2003), and Programa Nacional de Educación Sexual Integral (Law of 2006)). However, existing laws still limit the budget allocated to the programme, as well as women's access to it. Furthermore, in some provinces, religious practices still hamper actual application of the programme.

Brazil deserves a special note for its National Policy on Integral Health. This Policy benefits African-Brazilian and indigenous women in rural and urban areas, not only in terms of access to improved equipment but also regarding access to better health services, including access to contraception facilities and methods. In Chile, progress was made in humanization of childbirth. With the support of the Consultative Council for Women and Movements, contraception measures were implemented in public health centers, guaranteeing access to emergency contraceptives for girls over 14 years old, a controversial measure that faced resistance from the Catholic Church. Regarding legalization of abortion, Pdt. Fernández de Kirchner refused to engage with the issue during both terms. In Brazil and Chile, legalization of abortion was strongly rejected by religious groups, conservative groups in Congress, and some civil society groups. Nomination of committed academic feminist Eleonora Menicucci as SPM Minister (2012-2015) did little to advance decriminalization of abortion. Showing similarities with Brazil, Pdt. Bachelet has continued to push for legalization of abortion on three grounds: in case of rape, danger of death of the mother, and in case the fetus is non-viable.

It is important to note that successful governmental actions on gender equality depend not only on the political will of a given President. As Jalalzai (2015) argues, if the president has no support in parliament, it is highly unlikely that she will push her political agenda through. Hence the importance of political pressure of organized feminist groups in civil society, working in synergy with femocrats, and women's policy agencies, often associated with state feminism, as discussed in the previous section.

\section{The intersectionality of Gender justice in public policies: the cases of Argentina, Brazil and Chile}

This section examines three major areas of gender justice in public policies: a) convergences and dissonances in feminist approaches; b) the role of the State to ensure de jure and de facto equality, and c) the complexity inherent in recognition and distributive policy-making.

\subsection{Convergences and dissonances in feminist approaches to gender equality in public policies}

A plethora of works attests to the social and political gains of incorporating gender equality in public policies, not only in terms of reconfiguring public institutions, but also in terms of galvanizing the democratic fabric of Argentina, Brazil, and Chile. Despite these achievements, there is little research investigating the extent to which gender-sensitive public policies have tackled the intersectional nature of discrimination. There is even less scholarly research examining the relation between gender justice and intersectional discrimination in public policies. To date, however, there is consensus on the fact that the return to democratic regimes in the three targeted countries led to the development of new conceptual and legal frameworks, not only in the domain of human rights, but also regarding equality between the sexes as a problem of public policy. In a similar vein, more policy attention was given to alignment of national gender policies with international organisations and international normative frameworks such as the CEDAW Convention, the IV Women's World Conference (Beijing 1995) — with its subsequent Action Platform, World and Regional Conferences, and 
the Durban conference on racism. Significantly, these frameworks contributed to a new set of normative and institutional instruments on equality and non-discrimination, which inspired gender-responsive reforms during the 1980s and the 1990s.

Preliminary findings corroborate the fact that during the re-democratisation period, feminist and women's movements, through persistent advocacy and lobby work, managed to democratise the patriarchal hetero-normative fabric of policy-making in ways that were empowering to women. Important gains were achieved in terms of women's citizenship's rights, increased public awareness of the structural subjugation of women as political, economic and social subjects, and of their invisibility in institutions that were responsible for ensuring the well-being of men and women, on equal terms with each other.

As a result of the shift from gender blind to gender-equality policies, ${ }^{6}$ gender equality policies were implemented through an overall mainstreaming strategy. These strategies consistently questioned the social construction of gender in different areas of public policymaking, and the lack of recognition of women as subjects entitled to human rights, in particular the right to a life free from any form of violence. Gustá e Caminotti (2010) have highlighted the heterogeneity of mainstreaming efforts to push for gender equality in the region. The authors highlight three main features of mainstreaming strategies that Argentina, Brazil and Chile share: gender inequality, women's citizenship and women's representation. They argue that it is through consideration of these three pillars that engagement by the state with the issue of gender inequality can be best understood. According to them, a certain degree of public commitment did exist as illustrated by the proliferation of gender equality policies that emerged during the re-democratisation period, either in the form of Equal Opportunities Programmes or as Gender National Plans. A case in point is Chile, where mainstreaming gender equality into public policy-making was, for many years, the main goal of the Women's and Equality Ministry (SERNAMeg) and a spearhead of Bachelet's two periods in office. Chile has been praised and criticised for its achievements of mainstreaming gender equality in public policy-making. One external evaluation of SERNAM stresses that a key gain of the National Equality Plan for the period 2000-2010 was to mainstream gender in processes of institutional assessment, aiming to improve performance of public institutions (SERNAM 2005). However, several feminist NGOs have complained that Chile's gender mainstreaming strategy in public policies has been more top-down than bottom-up, and has excluded indigenous men and women, as well as LGTBI subjects (interview 2017). ${ }^{7}$

\subsection{The role of the State to ensure de jure and de facto equality}

Despite progress achieved during the re-democratisation processes, significant challenges remained after the paradigmatic transition from gender-blind to gender-equality public policies. A first challenge relates to the intersectional nature of inequality and discrimination. By intersectional inequality, we mean mechanisms of negative differentiation based on race, social class and ethnicity, amongst others, which result in a web of multiple discrimination against women, men and Trans persons in social, economic and political life.

\footnotetext{
${ }^{6} \mathrm{~A}$ study by the United Nation shows that during the nineties, a certain level of gender awareness could be perceived in the political, social and economic reforms that were undertaken (UNSRID 2005).

'The tension between mainstreaming efforts by public gender machineries such as SERNAM and women's perceptions of the relevance of these efforts vis-à-vis their priorities and political agendas can possibly be explained by the managerial edge of public mainstreaming efforts. As the SERNAM evaluation study suggests (SERNAM, 2005, p. 99), gender mainstreaming efforts were, to a certain extent, driven by technical goals (such as improving management and performance of public institutions) rather than politicalobjectives (for instance, to transform the unequal power relations affecting social interactions between heterogeneous men and women, both as individuals and as core groups).
}

6 Revista Estudos Feministas, Florianópolis, 26(3): e58565 
This is a challenge that public policies promoting gender equality have insufficiently addressed or simply overlooked. Engagement with overlapping factors of discrimination, which generate new forms and perpetuate old forms of inequality could better explain by which social, racial and cultural dynamics a "social marker of difference" becomes a factor of inequality, and what makes this shifting possible in a given context. As Staunaes (2003) argues, this is an important issue for comparative intersectional analysis of state policies promoting gender equality, since it calls for an examination of those unmarked social categories where power and privilege cluster (ctd. in YEON HAE, 2010: 133). In addition, it relocates discussion on how equality (or inequality, its binary opposite) works at the formal (de jure) and practical (de facto) level.

Echoing the critique made by Spelman (1988), several feminist scholars have criticized the lack of engagement by public policies with the persistent inequalities affecting black, indigenous and non-heterosexual men and women. The main contention is that in pushing for gender mainstreaming in policy-making, feminist theorising fell in the trap of conceptual sameness. This means that women and men were defined as homogeneous categories rather than heterogeneous subjects, and as universally subjugated by androcentric thinking and patriarchal policies, while overlooking the impact of racism and heteronormative discrimination on women and men whose subjectivity did not conform to hegemonic definitions of manhood and womanhood.

Of late, several scholars have pointed to the "gender fatigue" affecting engagement with gender equality in public policy-making. A major contention is that even though gender mainstreaming policies incorporated women's agendas and claims into public policymaking, they overlooked the matrix of intersecting discriminations affecting gender interactions in material reality. Moreover, several scholars have critiqued the epistemic privilege granted to women's discrimination as solely explained by their being a woman, hence their socially constructed gendered condition. Joining the critique of black Brazilian feminist scholars, De Paula argues that due to racial ideologies at work in the Brazilian social mindset, focus has been on the black subject as "other" and in a position of inequality to a universal ideal of subjectivity assumed as primarily white (2014, p. 149). Recalling the matrix of intersectional discrimination theorised by Patricia Hill Collins (2000), Cubillos (2015) regrets the epistemic privilege granted to gender discrimination in feminist theorising, adding that it is necessary to understand how power relations between the sexes interact with other discriminatory mechanisms to further disenfranchise black, indigenous and migrant women. Cubillos refers to a paradox that feminist theory wrought from its own theoretical canvas: in its efforts to deconstruct the peripheral location assigned to the female subject and the centrality of the male subject in patriarchal ideology, feminist theorising forgot to engage, on equal terms, with indigenous and black female subjectivity. In the same line of thought, Sueli Carneiro (2011) stresses the fact that the whiteness ideology continues to shape institutions and policy-making processes in ways that are disenfranchising to black men and women. ${ }^{8}$

The refusal of epistemic privilege informing gender mainstreaming in public policies appears to have invigorated debates on gender justice, a paradigm that is closely linked to global social justice movements. Gender justice claims have relocated de jure and de facto equality as a primary responsibility of the state and of its institutional fabric (the executive, the judiciary and the legislative). Gender justice debates, along with increased attention to the intersectional dimension of discrimination, have greatly contributed to the repolitisation of

${ }^{8}$ The critique against the predominance of racialised gender mainstreaming in public policy-making evokes the problem of intra-categorical hegemony. As pointed put by Crenshaw (1991) and McCall (2005), intracategorical hegemony occurs when an idea of hegemonic subjectivity is wrought from within a supposedly emancipatory theoretical fabric. 
the struggle for equality in Latin America. The nexus justice and rights, which Vergel defines as "conceptual collage" (2011), has served as a road map in the struggle for gender justice in the domain of civil and political rights, economic, social and cultural rights, sexual and reproductive rights. From this analytical angle, an idea of justice and fairness in policy frameworks has emerged, locating the state as the main duty-bearer, i.e. the main responsible for implementing policies and laws to guarantee the right to equality, both de jure and de facto (FACIO, 2008, p.11). ${ }^{9}$ Significantly, intersectional gender justice has also paved the way for relocating equality as a human right, with particular emphasis onthe indivisibility of individual and collective human rights, a key claim of women, men, and Trans persons belonging to peasant movements, to indigenous and afro-descendant peoples, to LGTTBI collectives. As Fríes (2011, p.2-3) points out in her analysis of the Chilean context, feminist movements have played a key role in the processes of recognition and protection of women's human rights. To indigenous legal scholars, some progress has been achieved at the level of recognition, but it is in the field of enforceability of these rights where the greatest challenge remains, in particular in relation to the collective rights of indigenous, black and LGTBBI groups and peoples. Referring to the gap between recognition and distributive policies, Fríes (201 1, p.4) argues that gender justice, understood as a matter of rights, has not yet materialized in the field of public policies in Chile.

From an intersectional equality standpoint, it appears that recognition and distributive policies are strongly related. Intersectional gender justice exposes the androcentric structure of legal and policy frameworks (social and economic)and the colonial legacy that prevents full compliance by the state with international conventions that guarantee the full enjoyment of right to de jure and de facto equality by indigenous, black and Trans subjects in Latin America. For this reason, MacKinnon (1982) and Crenshaw (1995) have insisted on the need to constantly deconstruct laws and policies, since they can also represent a hindrance to the achievement of non-discriminatory legal and policy arrangements.

\subsection{The bi-focality of gender justice: recognition and distributive policy-making}

One of the areas of greatest debate in gender justice is the relationship between the struggle for recognition of difference and distributive justice, the latter understood as equity in the distribution of wealth and resources resulting from economic activity in a given country or geographical area. This productive tension has given rise to rich theoretical debates. These debates have included claims for recognition of subaltern identities and subjectivities in local contexts, where claims for redistributive policies have relocated social class in the political agendas, highlighting its disenfranchising impact on the bodies and subjectivities of historically subjugated men and women.

Janet Fraser is amongst those scholars who have theorised on the false duality around recognition and redistribution. The author has argued that it is a "false antithesis" (2006: 84) and has warned against the danger of reification of the identities of groups and people who have struggled for the achievement of social justice, and in particular, of distributive justice. Echoing intersectionality theorists, she proposes a "bifocal" approach that defines gender justice as a paradigm that contains "intersected axes of subordination." These intersected axes produce and reproduce multiple and intertwined patterns of discrimination (i.e. discrimination based on gender, race, ethnicity, sex, age, cultural origin, amongst others). In

'The state's obligation to legislate and implement policies guaranteeing the right to equality has also been emphasised by feminist networks like HUMANAS (2017), which states that gender justice is not only a human right but also a state's duty towards citizens.

8 Revista Estudos Feministas, Florianópolis, 26(3): e58565 
doing so, Fraser locates the struggle for recognition of difference and the struggle for distributive justice in a plane of epistemological equity. In her theoretical proposal, through bifocality, Fraser calls for overcoming the conceptual monolithism inherent in unitary and exclusive struggles, and assuming that recognition and redistribution constitute a two-dimensional conception of social justice, "centered on the normative principle of parity of participation" (2008).

Inspired by Fraser's proposal, Valenzuela and Rangel point out that in Latin America there is an androcentric culture which controls interpretation and communication patterns that have naturalized exploitation. For this reason, the struggle against social injustice has tended to focus on recognition, despite a marked increase in distributional inequality (VALENZUELA; RANGEL, 2004). In her analysis of Argentina, Graciela Di Marco (2015) warns against a persistent reluctance to focus on redistribute policies (for example, income transfers, targeted policies, positive discrimination, quota policies), as the current trend is to meet market-driven demands (such as productivity) rather than social justice imperatives (such as the equitable distribution of wealth). Surprisingly as it may be, the reluctance to further implement distributive policies occurs in countries with persistent levels of inequality, as is the case of Argentina, Brazil and Chile.

Empirical evidence demonstrates that of the three countries chosen for comparison, Brazil is the one that shows the strongest concern with intersectional gender justice, addressing recognition and redistribution in gender equality policy-making (ABRAMO, 2008; LAVINAS, 2005). In the case of Brazil, the incorporation of intersectional analysis paved the way for making progress towards gender just policy frameworks. In contrast, evidence of this was not found in Chile and Argentina. In fact, several interviewed experts from Chile have regretted the lack of intersectionally disaggregated data sustaining gender equality policies. They contend that gender equality policies have tended to privilege focus on women's issues over social inequality. There is, however, strong awareness of the fact that, considering its comparative nature, intersectional data would be extremely useful in the design of more inclusive and genuinely just policy-making, for it would permit to expose the root causes of racism and homophobia, in their intersected correlation with gender discrimination. For reasons that would be worth investigating, awareness has not yet translated into innovative theorising on gender justice in the country. In Brazil, the relevance of redistributive policies for intersectional equality has been highlighted by scholars such as Lavinas. This author argues that redistributive measures, such an income policy for active households with children, investment to maintain social rights achieved through the right to citizenship, and increased social investment were, and still are, necessary to reduce gender differentials, ethnic and racial discrimination in Brazilian society (LAVINAS et al., 2005, p.3).

On a broader scale, it appears that in Argentina, Brazil and Chile, anti-distributive discourse has gained momentum, thus reducing the state's capacity to implement policies aimed at more equitable distribution of wealth and resources. Moreover, the challenges posed by the pressure on national economies to become more competitive in international markets has contributed to a shrinking of the state, with the consequent weakening of its capacity to design and implement policies that aim at the achievement of intersectional gender justice, both in its dimensions of equality de facto and equality de jure.

\section{Concluding remarks}

Several scholars have stressed the inextricable link between equality as a human right and the Rule of Law, in particular as it relates to institutional arrangements that guarantee equal access to justice, and reflect a concern with equality in policy design and 
implementation, including budgeting allocated to these programmes (LANQUETIN, 2013; $F A C I O, 2008$ ). The principle of non discrimination has been a fundamental element of the intersectional gender justice paradigm put forward by feminist scholars and women's movements. Assumed as a human right, intersectional gender justice implies that a state must design and enforce laws and policies guaranteeing equality of treatment and opportunities for all women, men and Trans persons. The right to intersectional gender justice does not only mean equitable access to justice, but also equitable access to decent livelihoods, and the right for every human being to enjoy his or her fundamental human rights (i.e. economic, political, sexual and reproductive rights) on equal terms with one another.

\section{References}

ABRAMO, Lais. "Trabajo, género y raza: un tema presente en la agenda brasileña". Nueva Sociedad, n. 218, p. 87-106, nov.-dic. 2008.

AVELAR, Lúcia; RANGEL, Patricia. "Como as Mulheres se Representam na Política? Os Casos da Argentina e do Brasil”. In: AVELAR, Lúcia; BLAY, Eva A. (Orgs.). 50 Anos de Feminismo: Argentina, Brasil e Chile. v. 1. São Paulo: Edusp, 2017.

BOHN, Simone R."Feminismo Estatal sob a Presidência Lula: o Caso da Secretaria de Políticas para as Mulheres." Revista Debates, v. 4, p. 81-106, jul./dez. 2010.

CARNEIRO, Sueli. "Enegrecer al feminismo". Documento iii Foro Ciudadanía Sexual. Córdoba, Fondo de Mujeres del Sur, 2001. Available en: http://mujeresdelsur.org/sitio/ images/ descargas/ennegrecer\%20el\%20feminismo sueli\%20carneiro.pdf. Acceso en 01/2017.

COSTA, Ana Alice Alcântara. Feminismo e Estado no Brasil: um feliz casamento? In: Seminário Internacional Fazendo Gênero, 8 " Corpo, violência e poder. Anais. 2008. Available at: http://www.fazendogenero. ufsc.br/8/sts/ST62/Ana_Alice_Alcantara_Costa_62.pdf

CRENSHAW, Kimberlé. "Mapping the Margins: Intersectionality, Identity Politics, and Violence against Women of Color", Stanford Law Review, v. 43, n. 6, p. 1.241-1.299, 1991.

CUBILLOS, Javiera. "La importancia de la interseccionalidad para la investigación feminista". Oximora: Revista Internacional de Ética y Política, v. 7, p. 119-137, 2015.

DI MARCO, Graciela. El pueblo feminista, movimientos sociales y lucha de las mujeres en torno a la ciudadanía. Buenos Aires: Editorial Biblos Sociedad, 2011.

JALALZAI, Farida. Women Presidents of Latin America: Beyond Family Ties. New York: Routledge Press, 2015.

HUMANAS. Centro Regional de Derechos Humanos y Justicia de Género. "Observatorio de sentencias." Humanas en Chile. http://www.humanas.cl. Acceso en 01/2017.

LAVINAS, Lena; DAIN, Sulamis. Proteção Social e Justiça Redistributiva: Como Promover a Igualdade de Gênero. Relatório Final Convênio Fase-Oxfam Novib. Rio de Janeiro, 2005.

McBRIDE, Dorothy E.; MAZUR, Amy G. The Politics of State Feminism: Innovation in Comparative Research.Filadélfia: Temple University Press, 2010.

MUÑOZ-CABRERA, Patricia. "La justicia de género en Latinoamérica: convergencias y disonancias en los marcos analíticos feministas." In: BLAY, Eva A.;AVELAR, Lúcia; RANGEL, Patrícia (Orgs). 50 anos de feminismo: Justiça de Gênero e Políticas Públicas: Argentina, Brasil e Chile. São Paulo: EDUSP, 2017.

HILL COLLINS, Patricia. "Intersecting Oppressions". Online article. available at:http://pinxit.com/ iframe-6/page105/downloads19/files/COLLINS_Intersectionality.pdf. Accessed 03/2017.

MACKINNON, Catherine. "Feminism, Marxism, Method, and the State: Toward Feminist Jurisprudence". Signs, v. 8, n. 4, p. 635-658, 1982. 
RODRIGUEZ GUSTÁ, Ana Laura; CAMINOTII, Mariana. "Políticas públicas de equidad de género: las estrategias fragmentarias de la Argentina y Chile". Revista Saap, v. 4, n. 1, ene./jun. 2010.

SCHEIDEGGER, Christine. Women's Policy Agencies and Institutional Architecture in Comparison: Building Blocks for Equal Gender Relations. 2014. Dissertation, University of St. Gallen, Switzerland. Bamberg: Difo-Druck.

SPELMAN, Elizabeth. Inessential Woman: Problems of Exclusion in Feminist Thought. Boston: Beacon Press, 1988.

STAUNAES, Dorthe. "Where have All the Subjects Gone? Bringing together the concepts of Intersectionality and Subjectification." NORA - Nordic Journal of Feminist and Gender Research, n. 11, p. 101-10, 2003.

VERGEL TOVAR, Carolina. "El concepto de justicia de género: teorías y modos de uso".Revista de Derecho Privado, n. 21, p. 119-146, 2011.

YEON CHOO, Hae; FERREE, Myra Marx. "Practicing Intersectionality in Sociological Research: A Critical Analysis of Inclusions, Interactions, and Institutions in the Study of Inequalities." Sociological Theory, v. 28, n. 2, p. 129-149, June 2010.

[Received on 08/08/2018

and accepted on $22 / 08 / 2018]$

\section{Justiça de gênero na análise feminista de políticas públicas em Argentina, Brasil e Chile}

Resumo: Este trabalho apresenta parte das pesquisas pós-doutorais de ambas as autoras (FFLCH) USP). O trabalho foca nos processos de transformação das ações governamentais sensíveis a gênero no Brasil, na Argentina e no Chile ao longo dos últimos anos, com especial atenção para os mandatos de presidentas (Cristina Fernández, Dilma Rousseff e Michele Bachelet). A partir de conceitos e tipologias da literatura especializada, abordam-se questões sobre a atuação de grupos de pressão e as disputas na arena política para compreender o impacto dos feminismos nas políticas públicas e buscar identificar se essas políticas de Estado atendem focos específicos da abordagem interseccional (gênero, raça/etnia, classe). Tratamos aqui, especialmente, de quatro grandes áreas de ações estatais (autonomia econômica, equipamentos sociais, violência, saúde) adotadas nos três países, observando dois aspectos em particular: 1) o papel das agências de políticas para mulheres e femocratas no processo de formulação e aprovação das políticas públicas; 2) justiça de gênero, ou convergências e dissonâncias na análise feminista (englobando temas como igualdade formal e substantiva, reconhecimento e justiça distributiva, a interseccionalidade da justiça de gênero). Nesse esforço, discutiremos o valor agregado das políticas de igualdade de gênero e resgataremos a problematização de políticas públicas como ações "neutras" ou "cegas ao gênero" vs. políticas públicas de gênero.

Keywords: Políticas públicas sensíveis a gênero, interseccionalidade, América do Sul, presidentas, justiça de gênero.

Patricia Muñoz-Cabrera (pmunozcabrera@cs.com) is a Post-doctoral fellow at the University of São Paulo - Faculty of Philosophy, Languages, Literature, and Humanities.

Patricia Duarte Rangel (pdrangel@gmail.com) is a Post-doctoral fellow at the University of São Paulo - Faculty of Philosophy, Languages, Literature, and Humanities; visiting scholar at the Institute for Latin American Studies of Freie Universität Berlin.

iD 0000-0002-3093-8011 